LBL -36519

UC 1600

To be published in Health Physics

\title{
NEW METHODS OF ENERGY EFFICIENT RADON MITIGATION
}

\author{
William J. Fisk ${ }^{*}$, Richard J.Prill ${ }^{*}$, John Wooley ${ }^{*}$, Y.C. Bonnefous ${ }^{*}{ }^{*}$, Ashok J.Gadgil , and \\ William J.Riley
}

\author{
Energy and Environment Division \\ Indoor Environment Division \\ Lawrence Berkeley Laboratory \\ University of California \\ Berkeley, CA 94720
'Washington State Energy Office Energy Extension Service Spokane, WA USA

${ }^{\ddagger}$ Groupe Informatique et Systemes Energetiques Ecole Nationale des Ponts et Chaussees Central 2, La Courtine, 93167 Noisey-le-Grand Cedex, France

We appreciate the assistance of Tim Nuzum in preparations for experiments and the thoughtful reviews of this document by Brad Turk, Ken Revzan, and Rich Sextro. This work was supported by the Assistant Secretary for Energy Efficiency and Renewable Energy, Office of Building Technologies, Building Systems and Materials Division of the U.S. Department of Energy (DOE) under contract No. DE-AC03-76SF00098. 
To be published in Health Physics

\title{
NEW METHODS OF ENERGY EFFICIENT RADON MITIGATION
}

\author{
William J. Fisk*, Richard J. Prill*', John Wooley*, Y.C. Bonnefous*', \\ Ashok J. Gadgil ${ }^{*}$, and William J. Riley* \\ *Indoor Environment Program \\ Energy and Environment Division \\ Lawrence Berkeley Laboratory \\ Berkeley, CA, USA \\ 'Washington State Energy Office \\ Energy Extension Service \\ Spokane, WA, USA \\ ${ }^{4}$ Groupe Informatique et Systemes Energetiques \\ Ecole Nationale des Ponts et Chaussees \\ Central 2, La Courtine, 93167 Noisey-le-Grand Cedex, France
}

13 May 1994

\begin{abstract}
Two new radon mitigation techniques are introduced and their evaluation in a field study complemented by numerical model predictions is described. Based on numerical predictions, installation of a sub gravel membrane at the study site resulted in a factor of two reduction in indoor radon concentrations. Experimental data indicated that installation of "short-circuit" pipes extending between the subslab gravel and outdoors, caused an additional factor of two decrease in the radon concentration. Consequently, the combination of these two passive radon mitigation features, called the membrane and short-circuit (MASC) technique, was associated with a factor of four reduction in indoor radon concentration. The energy-efficient active radon mitigation method, called efficient active subslab pressurization (EASP), required only $20 \%$ of the fan energy of conventional active subslab depressurization and reduced the indoor radon concentration by approximately a factor of 15 , including the numerically-predicted impact of the sub-gravel membrane.
\end{abstract}

\section{INTRODUCTION}

Inhalation of the radioactive decay products of radon $\left({ }^{222} \mathrm{Rn}\right)$ causes an estimated 13,000 cases of lung cancer annually in the United States (Lubin and Boice 1989). As a consequence of the high proportion of time spent indoors (approximately 90\%) and the elevation of indoor radon concentrations relative to outdoor concentrations, most of the exposure to radon decay products occurs indoors. In houses with high indoor radon concentrations, the primary source of radon is usually the nearby soil and the dominant process of radon entry is generally pressure-driven flow of radon-bearing soil gas through cracks and holes in the substructure (Nazaroff et al. 1988). The pressure differences that draw soil gas into houses, caused by the stack effect, wind, or exhaust 
fans, are typically a few pascals. Options for reducing indoor radon concentrations include modifying the pressure differences that drive radon entry, using subslab or crawl space ventilation to reduce concentrations of radon in the soil gas that enters the building, sealing openings between the soil and the house interior, and increasing the ventilation rate of the house.

\section{CONVENTIONAL SUBSLAB DEPRESSURIZATION AND PRESSURIZATION}

Active subslab depressurization (ASD) is the most commonly-utilized method of eliminating or reducing pressure-driven radon entry into buildings with basements or concrete slabs at grade level. In ASD, a small fan draws soil gas from beneath the slab usually through plastic pipes that penetrate the slab floor. This soil gas is exhausted to outside. Ideally, the soilgas pressure beneath all portions of the slab is reduced below the air pressure at the indoor surface of the slab, thus eliminating pressure-driven soil gas entry through the slab floor. The subslab depressurization causes the flow of indoor air through cracks into the subslab region. A depressurization of 125 to $400 \mathrm{~Pa}$ is often required where the ASD pipes penetrate the slab to ensure an adequate depressurization (e.g., $10 \mathrm{~Pa}$ ) beneath the slab several meters distant from the ASD pipe. A layer of clean and coarse gravel beneath the slab floor improves ASD performance by increasing the spatial extension of the depressurized zone around the ASD pipes (Bonnefous et al. 1992, Prill et al. 1992).

Active subslab pressurization (ASP) is a slightly different mitigation technology. The direction of air flow is reversed so that low-radon outdoor air is forced into the subslab region. The subslab region is ventilated with outdoor air, diluting subslab radon concentrations, and is also slightly pressurized. Pressure-driven flow of radon from surrounding soil into the pressurized subslab region is inhibited by ASP. The flow of air from the subslab gravel into the soil can also reduce or eliminate diffusive transport of radon into the gravel (Gadgil et al. 1994).

Numerous studies have demonstrated that ASD is often highly effective in reducing indoor radon concentrations (Henschel 1988, 1993), particularly when a layer of gravel is present between the slab and the soil. A more limited body of research has indicated the effectiveness of ASP systems (e.g., Turk et al. 1987, 1991). However, ASD and ASP have three major drawbacks-- a substantial initial cost, substantial energy consumption, and moving parts (i.e., fans) that create noise and eventually fail.

A typical initial cost for ASD systems is $\$ 1200$. (Henschel 1991) -- high enough to inhibit the installation of systems by new home builders and home owners. Over the life of a house, however, the energy costs associated with system operation are more significant. Typically a fan with a power consumption of approximately $90 \mathrm{~W}$ (Henschel 1991) is operated continuously. Such a fan consumes $2.8 \mathrm{GJ}(790 \mathrm{KWH})$ of electricity annually which costs $\$ 64$ at a typical electricity price $(\$ 0.08$ per $\mathrm{KWH})$. In some houses, multiple fans have been required for successful radon mitigation.

ASD systems also increase heating and air conditioning energy use because they often draw air from the basement through cracks and holes in the slab floor thereby increasing the ventilation rate. ASP systems also increase ventilation rates because they increase the rate of flow of air into the house through cracks and holes from beneath the slab floor. In seven houses located in the Pacific Northwest (Turk et al. 1987), the measured ventilation rate averaged $0.07 \mathrm{~h}$ $\left(0.005 \mathrm{~m}^{3} \mathrm{~s}^{-1}\right)$ higher after installation of ASD or ASP systems. In a study of five New Jersey houses (Turk et al. 1991), the estimated average increase in ventilation was $0.025 \mathrm{~m}^{3} \mathrm{~s}^{-1}$. Bonnefous et al. (1994) predicted ventilation rate increases of about $0.04 \mathrm{~m}^{3} \mathrm{~s}^{-1}$. In another study of three houses by Clarkin et al. (1990), the average increase in ventilation was $0.008 \mathrm{~m}^{3} \mathrm{~s}^{-1}$.

The energy penalty associated with the increased ventilation can be estimated. Using, for example, the moderately cold Chicago climate $\left(3600^{\circ} \mathrm{C}\right.$-days), assuming an increase in ventilation rate of $0.02 \mathrm{~m}^{3} \mathrm{~s}^{-1}$ (the average of the previously cited values) and a furnace efficiency 
of 0.7 , the annual increase in heating energy due to ASD operation is $10.6 \mathrm{GJ}$. At a natural gas cost of $\$ 5.7$ per GJ, the annual cost for increased heat is $\$ 42$. With electric resistance heat ( $\$ 0.08$ per KWH) the annual cost for increased heat is $\$ 165$. ASP systems will increase energy consumption and costs by a similar amount.

ASP systems will also affect the rate of heat gain or loss through concrete slab floors, because they force outdoor air (colder than soil temperature during winter and warmer than the soil during summer) to flow beneath the floors. The resultant increases in heating and cooling energy use have not been quantified.

The energy demand from these radon mitigation systems could become significant from the perspective of utilities or the nation as mitigation system use becomes more widespread. Approximately 3.6 million single family residences in the U.S. are expected to have annual average radon concentrations above the U.S. EPA guideline of $150 \mathrm{~Bq} \mathrm{~m}^{-3}\left[4 \mathrm{pCil}^{-1}\right]$ (Marcinowski 1992). If active ASD or ASP systems were eventually operating in half of these houses, fan operation alone would consume $5 \times 10^{6} \mathrm{GJ}$ of electricity annually costing 115 million dollars and emitting approximately $10^{9} \mathrm{~kg}$ of $\mathrm{CO}_{2}$ into the atmosphere (assuming the nationwide mixture of sources of electricity generation). Nationwide the peak power requirements would increase by $0.16 \mathrm{GW}$. If, for a first order estimate, one assumes that the increased heating energy from the previous example $(10.6 \mathrm{GJ})$ is typical, the annual increase in heating energy use would be $2 \times 10$ GJ.

The long-term reliability of ASD and ASP systems is another area of concern. Failed fans and fans turned off by home owners because of noise or energy use have been recorded in follow-up studies of ASD and ASP systems conducted only a few years after system installation (e.g., Prill et al. 1990, Gadsby and Harrje 1990, Scott 1990).

The previous discussion indicates that effective radon mitigation technologies with a lower energy consumption are needed. Ideally, the alternative technologies should have a lower initial cost than ASD and be entirely passive (i.e., should not use fans). One option that has been evaluated in a few tens of houses is passive stack depressurization system (e.g., Brennan et al. 1990, Saum and Osborne 1990, Saum 1991). This technology is similar to ASD except there is no fan, only a vertical pipe that passes through the heated section of the house. Buoyancy-driven air flow up the warm stack, analogous to the flow up a chimney, causes a small depressurization in the gravel at the base of the stack and inhibits pressure-driven radon entry through the slab floor. Depending on the wind speed and direction and stack location relative to the location of the roof of the house, wind pressures will have an uncertain variable impact on the stack-driven air flow. The reported investigations of passive stack depressurization have typically been short term, relatively simple in scope (few parameters were measured), and limited to a few geographic or geologic regions. The reported reductions in indoor radon concentrations associated with opening the passive stack have been variable, with a 50\% reduction being typical. A unique evaluation of passive stack systems was completed by Burkhart and Kladder (1991). They compared radon concentrations in two populations of houses (one with and one without passive stack systems) located in similar soils. The average concentrations in the two populations were "indistinguishable".

The remainder of this paper describes the first investigation of two new options for energy efficient radon mitigation- one entirely passive and the other relying on very low power fans.

\section{DESCRIPTION OF NEW RADON MITIGATION TECHNIQUES}

Membrane and Short-Circuit Technique

In the Membrane and Short-Circuit (MASC) method of radon mitigation, depicted in Fig. 1, a sub-gravel barrier to radon diffusion and pressure-driven flow is combined with a low- 
resistance pathway (short circuit) for fresh air flow between the subslab gravel and outdoors. The diffusion and flow barrier (membrane) would typically be several sheets of suitable plastic with overlapping edges, placed on top of the subslab soil and below the subslab gravel. Several installation options are possible. In the field study described subsequently, the plastic sheets terminated a few centimeters (i.e., as close as practical) from the inside edges of all concrete footings. Several sheets of plastic were used with an overlap of approximately $0.6 \mathrm{~m}$ at junctions. No attempt was made to create a seal where the sheets overlapped. Some openings must be present in the membrane to permit drainage of water from the gravel into the soil in instances where the gravel becomes saturated.

The membrane serves two primary purposes. It greatly reduces the rate of diffusion of radon from the soil into the gravel, assuming the radon diffusivity in the membrane is sufficiently small. The membrane also prevents pressure driven radon flow from the soil into the gravel except through the gaps and holes in the plastic sheets. In a previous paper (Bonnefous et al. 1993), numerical model predictions suggested that a sub-gravel membrane will reduce radon entry rates into houses with basements and subslab gravel layers by $10 \%$ to $50 \%$, depending primarily on the soil permeability. Another paper (Gadgil et al 1991) presents model predictions indicating that the membrane will improve the performance of ASD and ASP systems, especially in houses with basements surrounded by highly permeable soil. Because the membrane inhibits flow between the gravel layer and the soil, it makes the ASD (or ASP) system more effective in depressurizing or ( pressurizing) the gravel layer.

In the MASC system, the sub-gravel membrane is complemented by pathways (short circuits) for the flow of air between outdoors (above grade) and the gravel layer. In the field study, these short circuits were sections of insulated plastic pipe that penetrated the basement floor near its perimeter, ran upward among the inner edges of basement walls, and penetrated the basement walls above grade. The gaps between the pipes and the slab were sealed.

The thermal insulation around the short-circuit pipes limits the rate of heat transfer from the basement to the gas within the pipes. Heating of the air in the pipes will cause a stack effect that impedes flow of air downward into the gravel. When installed at the time of initial house construction, it would be preferable to route short-circuit pipes through the soil rather than through the warm basement.

For a future study, an alternative to plastic pipes will be considered. Drainage mats would be applied to the basement walls. Sections of horizontal plastic pipe installed through the footings or through the basement walls would connect the mats to the gravel, providing a low resistance pathway around the entire periphery of the structure for air flow between the gravel and the above-grade atmosphere. The essential elements of the drainage mats are a porous material, through which air can flow, in contact with the basement wall and an unbroken plastic membrane in contact with the soil. Several versions of drainage mats are commercially available.

Our initial concept of the performance of the MASC system is as follows. The subgravel membrane limits diffusive and pressure-driven transport of radon into the gravel as described previously (therefore, the membrane alone reduces indoor radon concentrations). The plastic pipes or drainage mat system provide pathways for flow of air between the above-grade atmosphere and the subslab gravel with a much lower flow resistance than the soil (hence the term "short circuits"). To understand the impact of the short circuits, first consider a situation without wind. Air flow into the gravel through the short circuits will reduce the magnitude of the depressurization in the gravel caused by a depressurization of the basement. Consequently, the rate of pressure driven radon entry into the gravel, and thus into the house, is decreased due to the presence of the short-circuit pipes. Now consider a situation with wind. Wind-generated pressures at the above-grade ends of the short-circuit pipes (or at the open edges of drainage mats) will cause air to flow into the gravel through some portions of the short circuit (e.g., 
through some pipes) and out through other portions of the short circuit. Thus, the wind ventilates the subslab gravel, reducing the concentration of radon in the gravel layer; hence, reducing the concentration of radon in gas drawn into the basement.

Calculations indicate that the short-circuit pipes or drainage mat system will not be effective without the sub-gravel membrane. Even if the short circuit pipes eliminated pressure driven flow of radon from the soil into the gravel, in many situations the rate of radon diffusion into the gravel would be sufficient to cause elevated indoor radon concentrations, when this radon is drawn into the house. Thus, the combination of a sub gravel membrane, which limits radon diffusion into the gravel, and short circuit pipes (or drainage mat) is necessary.

The MASC system requires no fan energy and should have a minimal impact on ventilation rates. The wind-driven flow of outdoor air beneath the floor may increase heating and cooling loads slightly due to increased heat conduction through the slab floor.

Although the authors developed the MASC concept independently, Kunz (1991) previously conceived of a very similar concept called "double barrier construction". Kunz did not undertake experiments or modeling to evaluate his approach.

\section{Energy-Efficient Active Subslab Pressurization}

An energy-efficient version of active subslab pressurization (Efficient-ASP or EASP) has also been studied. As in the MASC system, the slab floor is underlain by a layer of subslab gravel and a sub-gravel membrane. The membrane greatly reduces radon diffusion into the gravel. A fan, much smaller than used in conventional ASD or ASP systems, pressurizes the subslab gravel. Experiments were conducted using one or more approximately $10 \mathrm{~W}$ fans, similar to the "minifans" described by Saum (1991). Fan energy consumption is greatly reduced. The smaller fans are effective in pressurizing the gravel layer because the membrane inhibits air flow into the soil. With a sub-gravel membrane, adequate pressurization is obtained throughout the gravel layer with a smaller subslab pressurization where the ASP pipe(s) penetrate the slab (Gadgil et al 1991). Compared to conventional ASP, the average pressure difference across the slab is decreased with the EASP system. Consequently, EASP should cause a smaller increase in building ventilation rates, and thus, heating and air conditioning loads, compared to conventional ASP. In theory, a sub-gravel membrane should also greatly facilitate the performance of ASD systems-- permitting the use of smaller ASD fans..

\section{RESEARCH METHODS}

Description of Experimental Site

The MASC technology and EASP were studied experimentally in Spokane, WA in an occupied single-family house. The house has a basement and one above-grade floor. Forced-air furnace supply registers and return grills were located in the basement and upstairs. The house was the subject of a previous investigation (Prill et al. 1992) and already contained a sub-gravel membrane of $0.010 \mathrm{~cm}$ thick high density polyethylene. The soil surrounding the house has an unusually high permeability--about $5 \times 10^{-10} \mathrm{~m}^{2}$ at most measurement locations (Prill et al. 1992). The permeability and Forchheimer Factor of the subslab gravel had been previously measured and are $3 \times 10^{-7} \mathrm{~m}^{2}$ and $20 \mathrm{~s} \mathrm{~m}^{-1}$, respectively (Gadgil et al. 1991). The gravel would be classified as number 4 in the Standard Specification for Concrete Aggregates of the American Society of Testing and Materials. The thickness of the gravel layer (average is $11 \mathrm{~cm}$ ), the location of subslab footings, and other relevant geometric data were recorded during initial house construction.

As illustrated in Fig. 1, the subslab gravel layer is divided into two sections by a central concrete footer. These sections are referred to as "subslab bays". Four short-circuit pipes, $0.1 \mathrm{~m}$ in diameter, were installed-- two pipes extended into each of the two subslab bays, surrounded by 
concrete footings (see Fig. 1). Gravel was removed where the pipes terminated below the slab, resulting in pits approximately $0.01 \mathrm{~m}^{3}$ in volume. The plastic pipes were installed after house construction. If installed during construction, the pipes would terminate in pits more centrally located in the layers of subslab gravel or connect to lengths of perforated plastic pipe buried in the subslab gravel.

\section{Overview of Research Approach}

The rate of radon diffusion through a sample of the membrane was measured in the laboratory. Numerical modeling was completed to estimate the impact of the MASC technology on radon entry rates. Based on the favorable model projections, a decision was made to proceed with experiments. The house was then retrofitted by installing the four short-circuit pipes as illustrated in Fig. 1. Four minifans, based substantially on the design of Saum (1991), were also fabricated in a form that permitted easy installation in (and removal from) the short circuit pipes. A multi-parameter instrumentation system was fabricated and installed in the house. Between December 1992 and early May 1993, the house was cycled between various radon mitigation conditions at one-to-two week intervals while indoor radon concentrations and numerous other parameters were monitored.

\section{Measurement of Radon Diffusivity in Membrane}

To determine the diffusivity of radon in the membrane, a sample of the membrane was sealed between two cylindrical aluminum canisters. Air was passed through a radon source yielding a stream with a constant radon concentration of approximately $2 \times 10^{5} \mathrm{~Bq} \mathrm{~m}^{-3}(5400 \mathrm{pCi}$

$\left.\mathrm{l}^{-1}\right)$ This airstream was forced through one canister at approximately $150 \mathrm{~cm}^{3} \mathrm{~s}^{-1}$. Radon-free air was forced at the same flow rate through the second canister. Flow rates were adjusted slightly so that the pressure difference across the membrane was less than $0.5 \mathrm{~Pa}$. Multiple samples of the air exiting the canisters were collected in alpha scintillation cells. After a waiting period, the alpha activity in each cell was determined using a photomultiplier tube counting station. The initial concentrations of radon in the samples were then determined via a calibration after correcting for the background count rates of the cells.

The radon diffusivity, $\mathrm{D}$, was determined from the radon mass balance equation

$$
\frac{D A\left(C_{h i}-C_{l o}\right)}{t}-Q C_{l o}-\lambda C_{l o} V=0
$$

where $\mathrm{A}$ is the area of the membrane, $\mathrm{t}$ is the thickness of the membrane, $\mathrm{Q}$ is the rate of air flow through the low-concentration canister, $\mathrm{V}$ is the volume of the canister, $\lambda$ is the radioactive decay constant for radon, and $\mathrm{C}_{\mathrm{lo}}$ and $\mathrm{C}_{\mathrm{hi}}$ are the radon concentrations at the low-concentration and high-concentration sides of the membrane, respectively. The final term in the equation is negligible.

\section{Numerical Model Predictions}

A three-dimensional steady-state finite difference numerical model (Bonnefous et al 1992) of soil gas and radon transport was used to obtain preliminary estimates of the impact of the MASC technology on rates of radon entry. MASC system performance was estimated for a range of soil and gravel permeabilities and various sizes and locations of cracks and holes in the concrete slab. The depressurization of the basement relative to the soil was assumed to be temporally constant. Modeling was conducted assuming that the perimeter of the plastic membrane terminated $1 \mathrm{~cm}$ from the footing. The modeling did not account for wind-generated air pressures on the soil surface surrounding the building or on the outdoor ends of the shortcircuit pipes. The same model was used to estimate the impact of the sub-gravel membrane, 
without the short circuit pipes, on radon entry rates at the experimental site. To develop this estimate, radon diffusion through the membrane was neglected (see the Discussion) and the model was run using measured values of soil and gravel permeability and the actual geometry of the basement, subslab gravel, and footings.

\section{Instrumentation For Field Study}

For approximately one month prior to and after installation of the short-circuit pipes on 18 December 1992, radon concentrations in the basement were monitored using a continuous radon monitor connected to a data logger. At the end of January 1993, a personal-computerbased instrumentation and data acquisition system was installed in the house. This system monitored: (1) radon concentration upstairs and in the basement; (2) the speed of air flow in each short-circuit pipe (direction of flow was not determined); (3) forced air furnace operation (on versus off); (4) the pressure difference across the basement slab floor at a central location; (5) basement air temperature; (6) basement humidity; (7) the temperature of air in each short circuit pipe; and (8) the output signal of an infrared analyzer that measured the concentration of sulfur hexafluoride tracer gas at two locations, generally upstairs and in the basement. In addition, four additional differential pressure transducers were used in some experiments to measure either pressure differences across the basement slab floor at additional locations or pressure differences between points in the subslab gravel and a point in the soil approximately $1 \mathrm{~m}$ below the center of the slab floor. All instruments, except the velocity sensors, were calibrated before and after the three months of monitoring. The factory calibration was used for the velocity sensors. Table 1 indicates the types of instrumentation used and provides an estimate of measurement uncertainty.

For measurement of ventilation rate, sulfur hexafluoride tracer gas was injected at a constant rate both upstairs and in the basement using peristaltic pumps that drew pure tracer gas from storage bags and delivered it to the inlet side of a small fan. The flow rates of tracer gas injection were measured every one-to-t wo weeks using a bubble flow meter. The air exchange rate of the house was determined from a simple steady-state mass balance equation for a wellmixed zone

$$
N=I /(C V)
$$

where $\mathrm{N}$ is the air exchange rate (i.e., rate of outside air entry divided by the indoor volume), $\mathrm{I}$ is the total rate of tracer gas injection, $\mathrm{C}$ is the spatial- (upstairs and basement) and temporalaverage tracer gas concentration for the period, and $\mathrm{V}$ is the house volume. The ratio of basement to upstairs tracer gas concentration ranged from 0.75 to 0.83 .

The concentrations of radon in the sub-slab gravel were measured at 11 locations every one-to-two weeks, typically just before a change in operation of the radon mitigation technology. Samples were collected in alpha scintillation cells and analyzed as described previously.

In the routine monitoring protocol, instrumentation output signals were recorded every 10 minutes. In addition, the zeros of the pressure transducers and the zero of the infrared analyzer (during some periods) were recorded twice each day. During several short term experiments, 0.5 to two hours in duration, pressure differences and air velocities were recorded every 10,5 , or 1 second.

\section{RESULTS}

Diffusion of Radon Through the Sub-Gravel Membrane

In two experiments, the diffusivity of radon in the membrane was determined to be approximately $2 \times 10^{-12} \mathrm{~m}^{2} \mathrm{~s}^{-1}$. The uncertainty in this diffusivity is approximately $50 \%$ due to the uncertainty in measuring the low radon concentrations on the low-concentration side of the 
membrane. For comparison, the effective diffusivity of radon in soil is generally higher by a factor of $10^{4}$ to $10^{6}$ (Nazaroff et al. 1988).

The rate of radon diffusion through the $140 \mathrm{~m}^{2}$ membrane beneath the house, assuming a soil gas radon concentration of $37,000 \mathrm{~Bq} \mathrm{~m}^{-3}\left(1000 \mathrm{pCi}^{-1}\right)$,typical-to-high for the Spokane area, and a negligible radon concentration above the membrane would be approximately $0.1 \mathrm{~Bq} \mathrm{~s}$ ${ }^{1}\left(2.7 \mathrm{pCi} \mathrm{s}^{-1}\right)$. If all radon that diffused through the membrane entered the house, and the house ventilation rate was $0.4 \mathrm{hr}^{-1}$, this diffusion rate would produce an indoor radon concentration of less than $2 \mathrm{~Bq} \mathrm{~m}^{-3}\left(0.05 \mathrm{pCi}^{-1}\right)$, which is negligible.

\section{Estimate of Radon Emanation from the Gravel}

The MASC and EASP systems do not prevent pressure driven flow from the gravel into the basement. Consequently, MASC and EASP would be ineffective, if the emanation of radon from the subslab gravel was sufficient to cause a high indoor radon concentration. The total mass of gravel beneath the slab floor is approximately $25,000 \mathrm{~kg}$. Assuming a ${ }^{226} \mathrm{Ra}$ content typical of soils, $40 \mathrm{~Bq} \mathrm{~kg}^{-1}\left(1000 \mathrm{pCi} \mathrm{kg}^{-1}\right)$ and an emanation coefficient of 0.1 , typical for crushed gravel (Nazaroff et al. 1988), the total rate of radon release into the pore spaces of the gravel is $0.2 \mathrm{~Bq} \mathrm{~s}^{-1}\left(5.4 \mathrm{pCi} \mathrm{s}^{-1}\right)$. This generation rate could produce an indoor radon concentration of less than $3 \mathrm{~Bq} \mathrm{~m}^{-3}\left(0.1 \mathrm{pCi} \mathrm{l}^{-1}\right)$ assuming a house ventilation rate of $0.4 \mathrm{hr}^{-1}$ and that all the radon entered the house. Consequently, the rate of radon generation in the subslab gravel is negligible, unless the gravel has an unusually high ${ }^{226} \mathrm{Ra}$ content.

Numerical Model Predictions

The initial numerical modeling, neglecting wind-generated pressures, indicated that the MASC technology would cause $75 \%$ to $95 \%$ reductions in radon entry rates. This is the range of predicted performance for soil permeabilities between $10^{-11}$ and $10^{-9} \mathrm{~m}^{2}$ and gravel permeabilities varied between $2 \times 10^{-7} \mathrm{~m}^{2}$ and $6 \times 10^{-7} \mathrm{~m}^{2}$. The purpose of this modeling was to estimate the general potential of the MASC technology, thus, a generic basement geometry with a single subslab bay and a single short-circuit pipe terminating at a central location within the subslab gravel was used in the simulations. Radon diffusion through the subslab membrane was neglected, based on the low measured diffusion coefficient. Radon emanation from the gravel was also neglected.

Modeling was also conducted to evaluate the effect of the sub-gravel membrane on radon entry into the house when the short-circuit pipes were not present. Based on predictions for the house with and without a membrane, the membrane reduced radon entry rates by approximately a factor of 1.9 .

\section{Radon Concentrations and Radon Entry Rates}

Because upstairs concentrations were not measured prior to installation of the full instrumentation system, the assessment of mitigation system performance is based on the basement radon concentrations. Basement concentrations were typically $30 \%$ higher than upstairs concentrations. Fig. 2 illustrates the time-average measured basement radon concentrations for various experimental configurations. The predicted radon concentration in the absence of the membrane was based on the numerically predicted ratio of 1.9 discussed above. When the two short circuit-pipes connected to each subslab bay were open, basement radon concentrations were decreased by approximately another factor of two, thus the total estimated impact of the membrane plus short-circuit pipes was to reduce radon concentrations by approximately a factor of 4 (i.e., $75 \%$ ) from the no-action reference case. Opening only one short-circuit pipe connected to each subslab bay appeared to cause no reduction in radon concentrations. These experimental results with only one open pipe per bay are inconsistent with 
the preliminary model predictions indicating that a single pipe would substantially reduce indoor radon concentrations.

Using one or two minifans per subslab bay to pressurize the subslab gravel was a highly effective mitigation technology. The average basement radon concentration was approximately $60 \mathrm{~Bq} \mathrm{~m}^{-3}\left(1.6 \mathrm{pCi} \mathrm{l}^{-1}\right)$, almost a factor of 15 below the estimated radon concentration in the absence of any mitigation system. The basement radon concentration was only slightly higher when a single minifan supplied air to only one subslab bay; however, only one week of data are available for this configuration.

The "error" bars on Fig. 2 indicate that basement radon concentrations were quite temporally variable, both with and without the short-circuit pipes open. Thus, the MASC technology did not maintain indoor radon concentrations at a low value during all time periods. However, the EASP system continuously maintained indoor radon concentrations at a low value.

Fig. 2 also illustrates the radon entry rates for the same experimental configurations. The radon entry rates are the products of the measured house-average radon concentrations and whole-house ventilation rates. (Average ventilation rates for the various one-to-two-week experimental periods ranged from 0.21 to $0.42 \mathrm{~h}^{-1}$.) The trends in radon entry rates are very similar to the previously discussed trends in the basement radon concentrations.

\section{Subslab Radon Concentrations}

For each mitigation system configuration, Table 2 lists the average concentration of radon in the scintillation cell grab samples collected from locations in the subslab gravel. Both the MASC and EASP techniques were expected to reduce the concentration of radon in the gravel. Although the measurements indicate a concentration decrease, concentrations are only $20 \%$ lower when the short circuit pipes are open, compared to sealed. However, using one or two minifans to force outdoor air into each subslab bay reduced the concentration of radon in the gravel bed to a negligible value. Because the subslab radon grab samples were taken only weekly or every other week, they may not accurately indicate time-average subslab radon concentrations.

\section{Pressure Differences}

The time-average pressure differences across the basement slab floor at the location of Hole 5 (see Fig. 1) are also listed in Table 2 for each mitigation system configuration. The pressure difference at this single central location, far from the short-circuit pipes, was not substantially affected by opening or sealing the short-circuit pipes. We did not measure pressure differences across the slab near the perimeter slab-to-wall joint which is considered a common location of radon entry. Using one or two minifans to force outdoor air into each subslab bay caused a factor of three increase in pressure difference at the centrally-located Hole 5.. Using a single minifan to supply air to one subslab bay, did not affect the pressure difference at this test hole located in the other subslab bay.

For a period with all four short-circuit pipes open, Fig. 3 illustrates the rapid temporal variability in the subslab gravel pressures relative to the pressure in the soil approximately one meter below the center of the basement slab floor. These pressure differences are an indication of the driving force for pressure driven flow of radon from the soil into the gravel. At some locations the pressure difference fluctuates between positive and negative values. These oscillations were considerably damped, but still evident, when all short-circuit pipes were sealed. The furnace system was inactive during this period, thus, cycling of the furnace did not cause the pressure fluctuations. As discussed subsequently, time varying winds are a suspected cause of these pressure oscillations. 
Air Speeds in the Short Circuit Pipes

When the short circuit pipes were open and minifans were not installed, the speed of air flowing through the short-circuit pipes was highly variable as illustrated in Fig. 4. Rapid changes in air speed were common, for example a change by $20 \mathrm{~cm} \mathrm{~s}^{-1}$ during a $50 \mathrm{~s}$ period. The pattern of air speed makes one suspect that the direction of air flow also varied. This suspicion was confirmed by observing the flow of smoke injected at the outside ends of the pipes. With minifans operating, a typical air speed in the short-circuit pipes was $150 \mathrm{~cm} \mathrm{~s}^{-1}$ corresponding to a flow rate of approximately $0.01 \mathrm{~m}^{3} \mathrm{~s}^{-1}$.

\section{DISCUSSION}

\section{MASC Technology}

This study has demonstrated that the MASC approach can substantially reduce timeaverage indoor radon concentrations when at least two short-circuit pipes are connected to each subslab gravel bay. Approximately half of the $75 \%$ total reduction in indoor radon concentration was the measured consequence of opening the short circuit pipes. The other half of the reduction in radon concentration, due to the impact of the sub-gravel membrane, was estimated based on numerical simulations.

One would expect the MASC system to cause larger reductions in indoor radon concentrations if the basement was surrounded by a more typical soil with a lower permeability. (The MASC technology requires the resistance to flow through the soil to be large compared to the resistance to flow through the short circuit pipes.) Termination of the short-circuit pipes more centrally in the subslab gravel bays should also result in improved performance. On the other hand, use of a less permeable aggregate would decrease MASC system performance. Considerable additional field experience is required to evaluate the MASC technology. However, given the low initial cost and small operating cost for the MASC technology, further studies are clearly warranted.

The apparent ineffectiveness of the MASC technology with only one open short circuit pipe per subslab bay was surprising and inconsistent with the preliminary model predictions. Time varying wind-generated pressures may be an explanation. Wind will cause pressure increases in the short circuit pipes located on the windward side(s) of the house and will also cause pressures to increase on the surface of the soil located near the windward side of the house. Pressures will decrease on the leeward side(s) of the house. The pressure increases or decreases will be transferred via the short circuit pipes to the subslab gravel. Oscillations in the wind pressures may cause a pumping action that draws radon into the subslab gravel and then helps to drive radon into the house. This hypothesis is consistent with the observed rapid pressure variations (between gravel and soil) illustrated in Fig. 4 and also consistent with the rapid variation in the speed of air flow through the short circuit pipes (Figure 5).

The relative success of the MASC technology with two open pipes per bay may also be substantially a consequence of wind pressures. The wind may cause air to flow in one pipe, through the gravel bed, and out the second pipe--ventilating the subslab gravel. This ventilation should reduce radon concentrations in the gravel. The measured concentrations of radon in the gravel were only $20 \%$ lower with two open pipes per bay (relative to all pipes sealed) and this $20 \%$ reduction is inadequate to explain a $50 \%$ drop in indoor radon concentration. However, the subslab radon concentrations were measured only infrequently. Wind driven ventilation of the subslab gravel would improve if air could easily flow between the two subslab gravel bays, for example, if sections of horizontal pipe were installed through the central footing. 


\section{Efficient ASP}

The EASP system was very effective in maintaining low indoor radon concentrations. Concentrations of radon in the subslab gravel were also maintained very low, indicating that the small low-power fans were effective in pressurizing the gravel relative to the soil. The use of two small fans with a combined power consumption of $20 \mathrm{~W}$ was clearly adequate. No attempt was made to optimize the system, thus, even lower power fans or the use of a single 10W fan that supplies air to both subslab bays may also maintain low indoor radon concentrations.

Based on our previous modeling and experiments, much larger, noisier, higher power fans would have been necessary if the sub-gravel membrane were absent. Henschel (1991) lists $90 \mathrm{~W}$ as a typical fan power requirement for ASD systems, and ASP systems should require a similar size fan. Turk et al. (1987) report the fan powers required when optimized ASP systems were used at four other houses in the Spokane area. As in the present study, these houses were constructed in highly permeable soil with moderate soil gas radon concentrations. However, in the studies by Turk et al. (1987), there were no sub-gravel membranes and, at least in some houses, no layers of subslab gravel. The average fan power was $130 \mathrm{~W}$. These comparisons suggest that fan power can be reduced by 70 to $110 \mathrm{~W}$ when EASP is employed.

Based on the lower ( $70 \mathrm{~W}$ ) estimate of fan power reduction, the annual electricity savings in a house would be $2.2 \mathrm{GJ}(613 \mathrm{KWH})$, worth about $\$ 50$ at an electricity price of $\$ 0.08$ per KWH. A continuous decrease of $70 \mathrm{~W}$ in $50 \%$ of the US houses with radon concentrations above the EPA guideline translates into annual electrical energy savings of $3.9 \times 10^{6} \mathrm{GJ}$ and a peak power reduction of $130 \mathrm{MW}$.

Additional energy savings will occur because the EASP system, compared to conventional ASP, will cause a smaller increase in the house ventilation rate and thus a smaller increase in energy for heating and air conditioning. Further research is required before these energy savings are quantified.

\section{CONCLUSIONS}

Based on the first field trials of two new radon mitigation techniques, both appear to have substantial merit. The passive MASC technology is attractive because of its low cost, low energy consumption, and lack of any moving parts; however, reductions in radon concentration were temporally variable and averaged only a factor of four. Half of the factor of four reduction is the numerically-predicted (hence more uncertain) impact of the sub-gravel membrane. Substantial additional field research is required to determine the typical effectiveness of the MASC technology. The active mitigation technology, EASP, reduced radon concentrations by approximately a factor of 15 , including the predicted impact of the sub-gravel membrane, and saved considerable energy compared to conventional ASP or ASD systems. Although further research is required, EASP and Efficient-ASD are expected to be effective for a wide range of housing and soil conditions and climates.

\section{ACKNOWLEDGMENTS}

We appreciate the assistance of Tim Nuzum in preparations for experiments and the thoughtful reviews of this document by Brad Turk, Ken Revzan, and Rich Sextro. This work was supported by the Assistant Secretary for Energy Efficiency and Renewable Energy, Office of Building Technologies, Building Systems and Materials Division of the U.S. Department of Energy (DOE) under contract No. DE-AC03-76SF00098. 


\section{REFERENCES}

Bonnefous, Y.C., Gadgil, A.G., Fisk, W.J., Prill, R.J., and Nematollahi, A.R. (1992) "Field study and numerical simulation of subslab ventilation systems." ES\&T 26 (9), pp. 1752 - 1759.

Bonnefous, Y.C., Gadgil, A.G., and Fisk, W.J. (1994) "Impact of subslab ventilation technique on residential ventilation rate and energy costs." Energy and Buildings 21, pp. 15-22.

Bonnefous, Y.C., Gadgil, A.J., Revzan, K.L., Fisk, W.J., and Riley, W.J. (1993) "Impacts of a sub-slab aggregate layer and a sub-aggregate membrane on radon entry rate: a numerical study" Proceedings of Indoor Air'93 The 6th International Conference on Indoor Air Quality and Climate, vol. 4, pp. 569-574, July 4 - 8, 1993, Helsinki, Finland. Published by -Indoor Air' 93, Helsinki.

Brennan, T., Clarkin, M., Osborne, M.C., and Brodhead, B. "Evaluation of radon-resistant new construction techniques", Proceedings of the 1990 International Symposium on Radon and Radon Reduction Technology: Preprints, vol. V, paper VIII-1, Published by the U.S. EPA, Office of Research and Development, EPA/600/9-90-005e, Research Triangle Park, NC.

Burkhart, J.F. and Kladder D.L. (1991) "A comparison of indoor radon concentrations between preconstruction and post-construction mitigated single family dwellings", Proceedings of the 1991 International Symposium on Radon and Radon Reduction Techniques: Preprints", vol.4, Paper VIII-2, Published by the U.S. EPA Office of Research and Development, Research Triangle Park, NC.

Clarkin, M., Brennan, T., and Osborne, M.C. (1990) "Energy penalties associated with the use of a sub-slab depressurization system" Proceedings of the 1990 International Symposium on Radon and Radon Reduction Technology: Preprints, vol. IV, paper D-VII-1, Published by the U.S. EPA, Office of Research and Development, EPA/600/9-90-005d, Research Triangle Park, NC.

Gadgil, A.J., Bonnefous, Y.C., Fisk, W.J., Prill, R.J., and Nematollahi, A.R. (1991) "Influence of subslab aggregate permeability on SSV performance." Lawrence Berkeley Laboratory Report, LBL-31160, Berkeley, CA.

Gadgil, A.J., Bonnefous, Y.C., Fisk, W.J. (1994) "Relative effectiveness of sub-slab pressurization and depressurization systems for indoor radon mitigation: studies with an experimentally verified numerical model" Indoor Air 4, pp. 265-274.

Gadsby, K.J. and Harrje, D.T. (1990) "Durability of subslab depressurization radon mitigation system performance", "Proceedings of Indoor Air'90 The 5th International Conference on Indoor Air Quality and Climate, vol. 3, pp. 445-450, July 29 - August 3, 1990, Toronto. Published by International Conference on Indoor Air Quality and Climate, Ottawa.

Henschel, D.B. (1988) "Radon reduction techniques for detached houses-technical guidance (second edition)" U.S. EPA, Office of Research and Development, EPA/625/5-87/019: pp. 87-146, Research Triangle Park, NC.

Henschel D.B. (1991) "Cost analysis of soil depressurization techniques for indoor radon reduction", Indoor Air 1(3), pp. 337-351.

Henschel, D.B. (1993) "Radon reduction techniques for existing detached houses-technical guidance (third edition)" U.S. EPA, Office of Research and Development, EPA/625/R93/011, pp. 24-52, Research Triangle Park, NC.

Kunz, C. (1991) Radon reduction in new construction: double barrier approach" Proceedings of the 1991 International Symposium on Radon and Radon Reduction Techniques: Preprints", vol.4, Paper VIII-3, Published by the U.S. EPA, Office of Research and Development, Research Triangle Park, NC.

Lubin, J.H., and Boice J.D. Jr. (1989) "Estimating Rn-induced lung cancer in the United States" Health Physics 57, pp. 417-427. 
Marcinowski, F. (1992) "Nationwide survey of residential radon levels in the U.S." Radiation Protection Dosimetry (1/4), pp. 419-424.

Nazaroff, W.W. , Moed, B.A., and Sextro, R.G. (1988) "Soil as a source of indoor radon: generation, migration, and entry", In Radon and its decay products in indoor air. W.W. Nazaroff and A.V. Nero, Eds. John Wiley \& Sons, New York, pp. 57-112.

Prill, R.J., Fisk, W.J. and Turk, B.H. (1990) "Evaluation of radon mitigation systems in 14 houses over a two-year period." J. Air Waste Manage. Assoc. 40, pp. 740-746.

Prill, R.J., Fisk, W.J., and Gadgil, A.G. (1992) "Factors that influence pressure field extension in new residential construction: experimental results." Proceedings of the 1992 Symposium on Radon and Radon Reduction Technology: Preprints, vol. 4, September 22 - 25, Minneapolis, MN. , Published by the U.S. EPA, Office of Research and Development, Paper XI-5, EPA 648-003/60,022, Research Triangle Park, NC.

Saum, D.W. and Osborne, M.C. (1990) "Radon mitigation performance of passive stacks in residential new construction" Proceedings of the 1990 International Symposium on Radon and Radon Reduction Technology: Preprints, vol. V, paper VIII-2, Published by the U.S. EPA, Office of Research and Development, EPA/600/9-90-005e, Research Triangle Park, NC.

Saum, D.W. (1991) "Mini fan for SSD radon mitigation in new construction" Proceedings of the 199I International Symposium on Radon and Radon Reduction Techniques: Preprints", vol.4, Paper VIII-5, Published by the U.S. EPA, Office of Research and Development, Research Triangle Park, NC.

Scott, A.G. (1990) "Long-term performance and durability of active Radon mitigation systems in eastern Pennsylvania houses", Proceedings of the 1990 International Symposium on Radon and Radon Reduction Technology: Preprints, vol. IV, paper VII-8, Published by the U.S. EPA, Office of Research and Development, EPA/600/9-90-005d, Research Triangle Park, NC.

Turk, B.H., Prill, R.J., Fisk, W.J., Grimsrud, D.T., Moed, B.A., and Sextro, R.G. (1987) "Radon and remedial action in Spokane river valley homes, volume 1: experimental design and data analysis." Lawrence Berkeley Laboratory Report, LBL-23430, Berkeley, CA.

Turk, B.H., Harrison, J., and Sextro, R.G. (1991) "Performance of radon control systems", Energy and Buildings 17, pp. 157-175. 
Table 1. Instrumentation used with the continuous monitoring system.

\begin{tabular}{|c|c|c|c|}
\hline Parameter Monitored & Type of Instrument & Measurement Range & $\begin{array}{l}\text { Estimated } \\
\text { Uncertainty }\end{array}$ \\
\hline Pressure Difference & $\begin{array}{l}\text { Electronic Pressure } \\
\text { Transducer }\end{array}$ & $0-25 \mathrm{~Pa}$ & $0.3 \mathrm{~Pa}$ \\
\hline Air Velocity & Thermal Anemometer & $0.05-2.0 \mathrm{~m} / \mathrm{s}$ & $\preceq 0.06 \mathrm{~m} / \mathrm{s}$ \\
\hline Air Temperature & Type T Thermocouple & $-160-400^{\circ} \mathrm{C}$ & $1^{\circ} \mathrm{C}$ \\
\hline Relative Humidity & $\begin{array}{l}\text { Variable Resistance } \\
\text { RH Transducer }\end{array}$ & $10-95 \%$ & $\pm 5 \% \mathrm{RH}$ \\
\hline $\begin{array}{l}\text { Radon Concentration } \\
\text { (upstairs and basement) }\end{array}$ & $\begin{array}{l}\text { Continuous Radon } \\
\text { Monitor }\end{array}$ & $\begin{array}{l}\sim 7->200 \mathrm{kBq} \mathrm{m}^{-3} \\
\sim 0.2->5.4 \mathrm{kpCi} \mathrm{l}^{-1} \\
\end{array}$ & $\leq 10 \%$ \\
\hline $\begin{array}{l}\mathrm{SF}_{6} \text { Tracer Gas } \\
\text { Concentration }\end{array}$ & $\begin{array}{l}\text { Infrared Analyzer, } 14 \\
\mathrm{~m} \text { path, } 10.55 \mu \mathrm{m}\end{array}$ & $0-140 \mathrm{ppb}$ & $10 \%$ \\
\hline
\end{tabular}


Table 2. Average subslab radon concentrations and pressure differences across slab.

\begin{tabular}{l|c|c}
\hline Mitigation System Configuration & $\begin{array}{c}\text { Avg. Subslab Radon } \\
\text { Concentration } \\
\mathrm{Bg} \mathrm{m}^{-3}\left[\mathrm{pCi}^{-1}\right]\end{array}$ & $\begin{array}{c}\text { Avg. Pressure Diff. at } \\
\text { Hole \#5 (Pa) }\end{array}$ \\
\hline $\begin{array}{l}\text { All Short-Circuit Pipes Closed } \\
(1032 \mathrm{hr})\end{array}$ & $16000[430]$ & 3.2 \\
\hline $\begin{array}{l}\text { Two Short-Circuit Pipes Open } \\
\text { Per Subslab Bay (958 hr) }\end{array}$ & $12000[320]$ & 3.4 \\
\hline $\begin{array}{l}\text { One Short-Circuit Pipe Open Per } \\
\text { Subslab Bay (172 hr) }\end{array}$ & $15000[400]$ & 10.9 \\
\hline $\begin{array}{l}\text { One or Two Minifans Per } \\
\text { Subslab Bay (665 hr) }\end{array}$ & $100[2.7]$ & 3.4 \\
\hline One Minifan Operating (213 hr) & $80[2]$ & \\
\hline
\end{tabular}

* Gravel pressure minus basement pressure 
Figure Captions

Figure 1. Plan view of the basement floor indicating location of short circuit pipes and test holes. A cross-sectional view showing the short-circuit pipe and sub gravel membrane is also shown.

Figure 2. Average basement radon concentrations and radon entry rates. The error bars indicate plus and minus one standard deviation in a 24-hour running average of the measured radon concentrations.

Figure 3. Example of the temporal fluctuations in pressure difference between locations in the subslab gravel and a location in the soil approximately $1 \mathrm{~m}$ below the center of the basement floor. A positive value indicates that the gravel pressure exceeds the soil pressure. Data were collected at one second intervals on April 7 1993. All four short-circuit pipes were open.

Figure 4. Example of temporal fluctuations in the speed of air in the short circuit pipes. Data were collected at one second intervals on March 1, 1993 during a period of gusty wind. All four short-circuit pipes were open. 

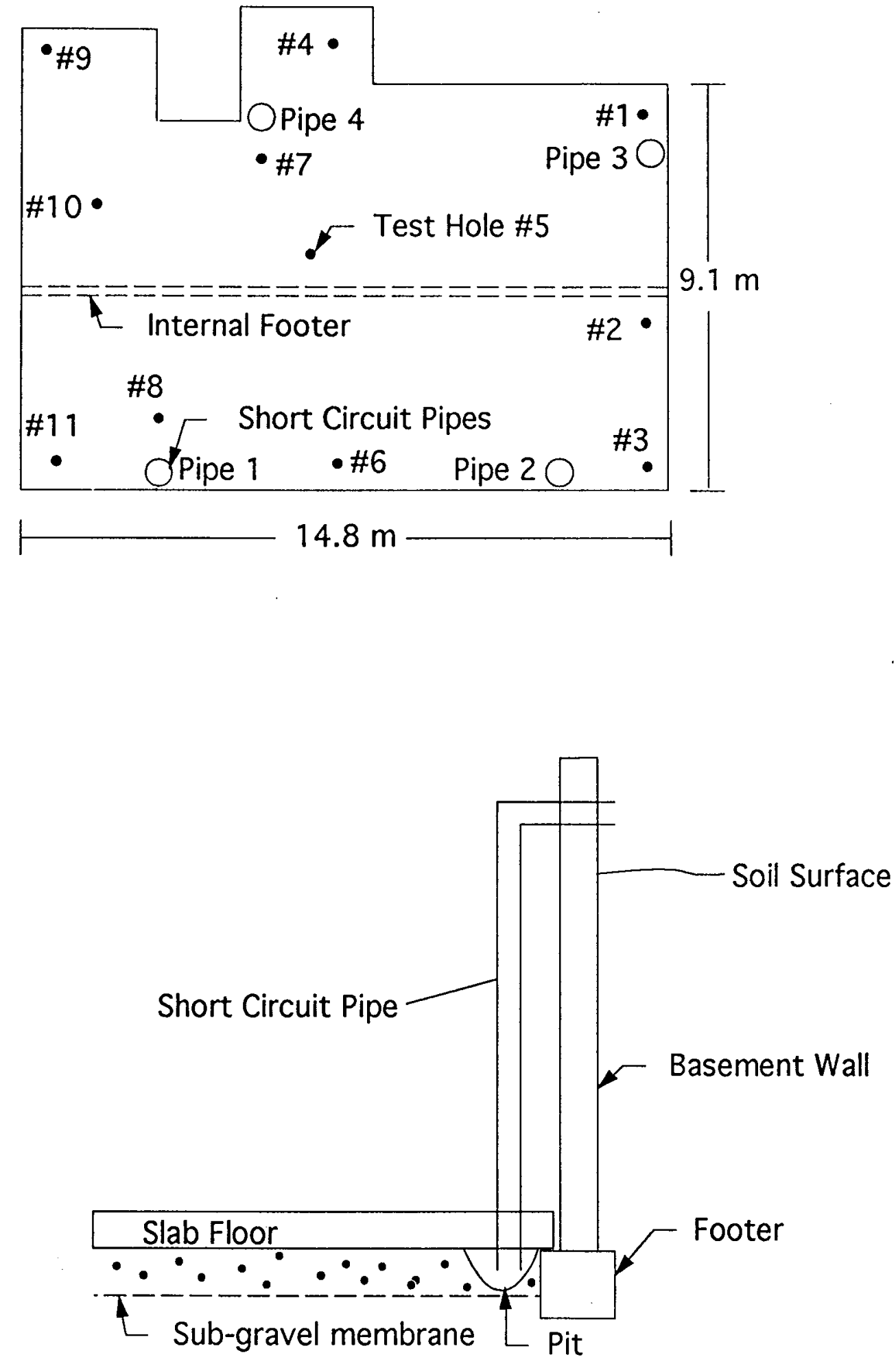
Chartl

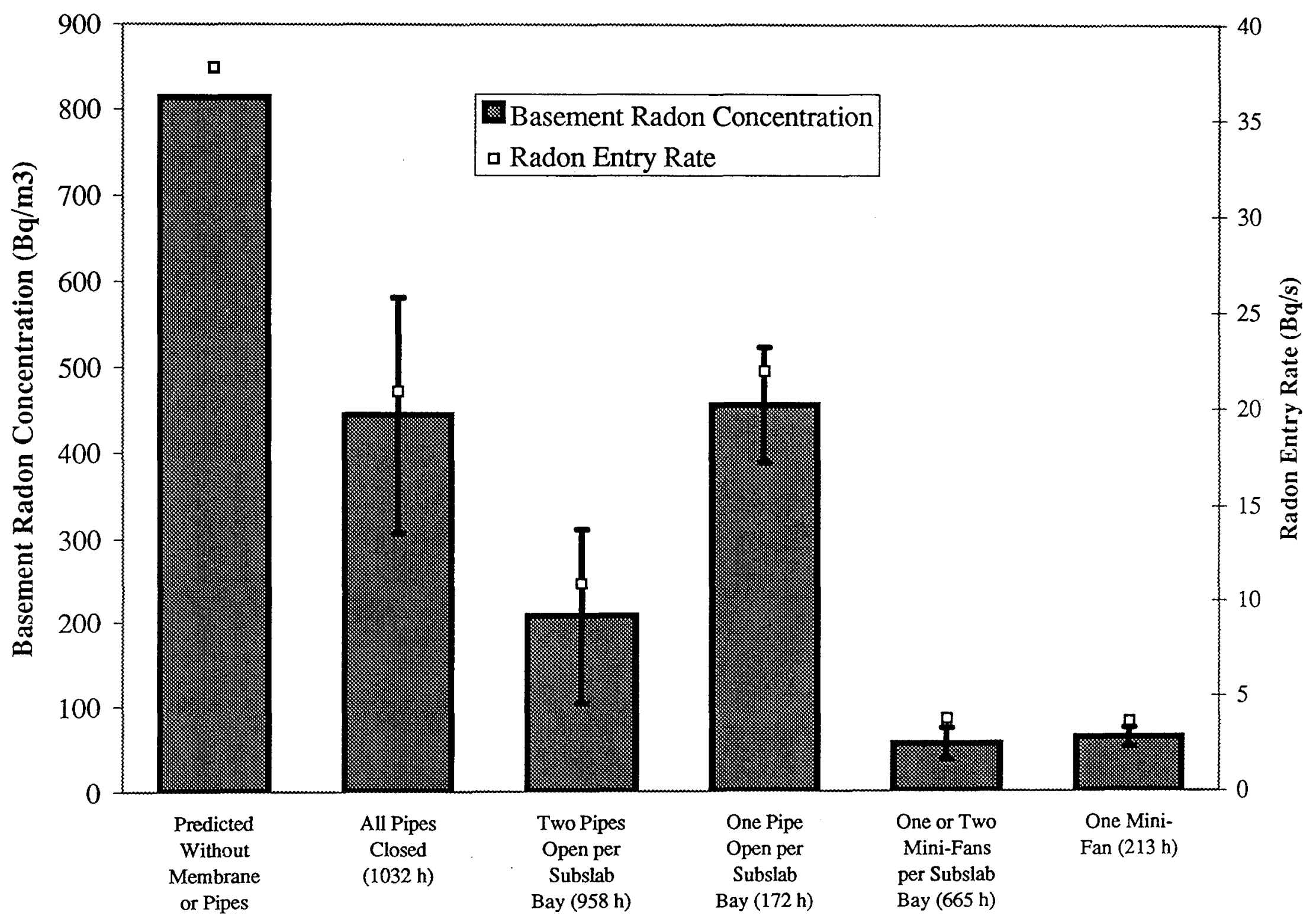


A-0407C.XLS Chart 1

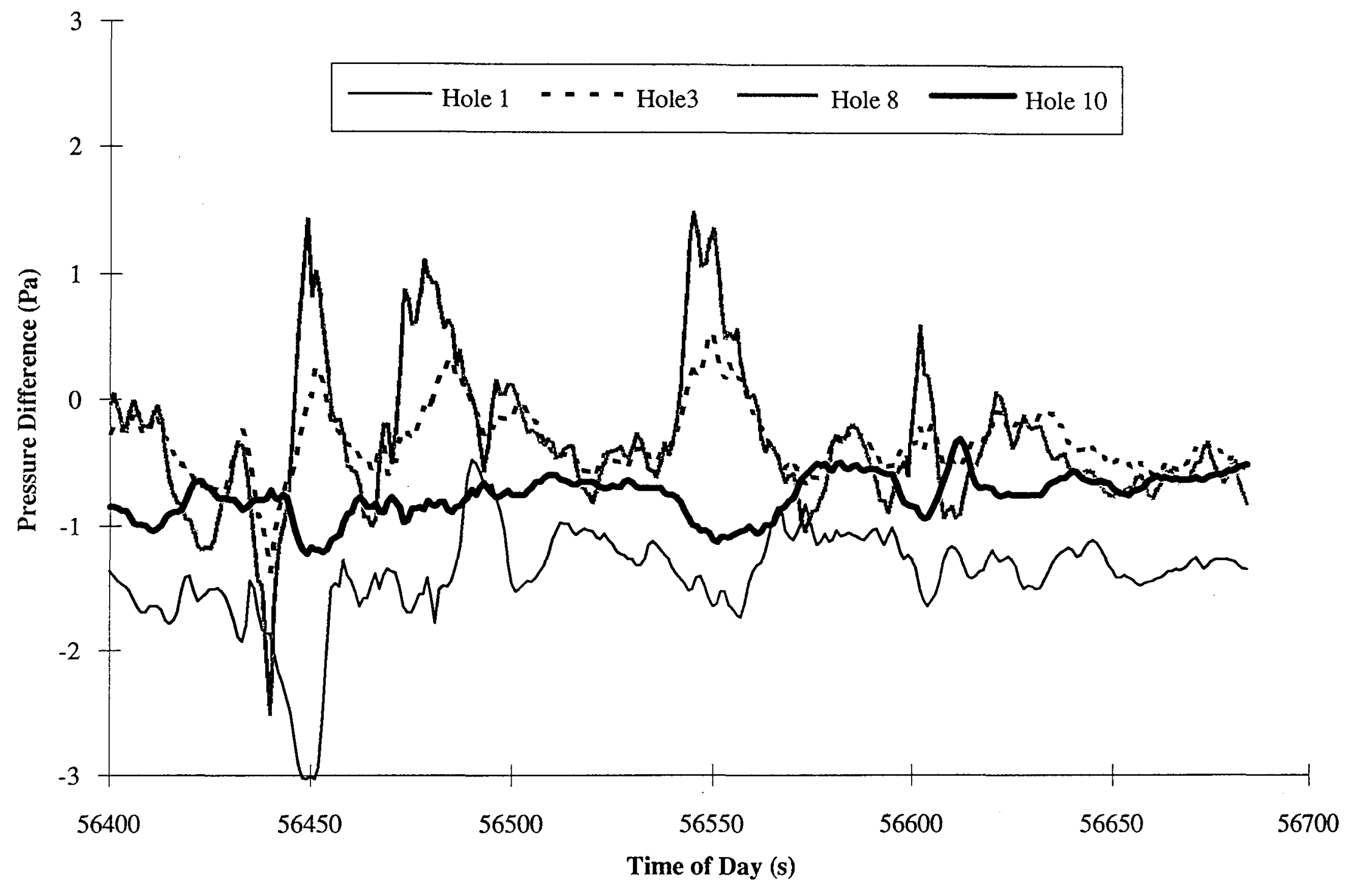




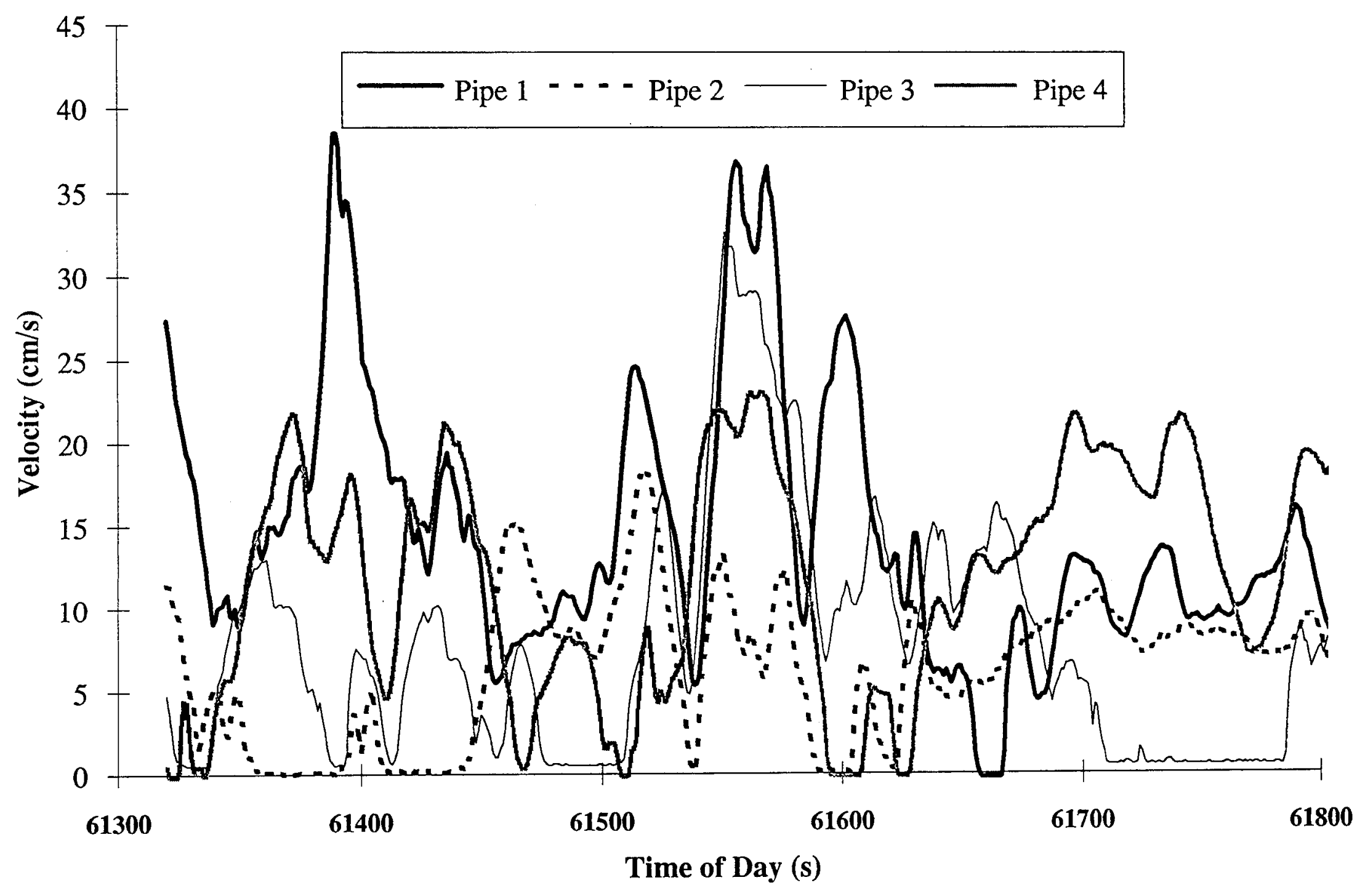


LEGAL NOTICE

This report was prepared as an account of work sponsored by the United States Government. Neither the United States nor the Department of Energy, nor any of their employees, nor any of their contractors, subcontractors, or their employees, makes any warranty, express or implied, or assumes any legal liability or responsibility for the accuracy, completeness or usefulness of any information, apparatus, product or process disclosed, or represents that its use would not infringe privately owned rights. 